\title{
Mulemba
}

Revista Angolana de Ciências Sociais

4 (8) | 2014

Globalização, gestão e dinâmicas de desenvolvimento regional e local

\section{Tradição, modernidade e mudança social em Angola}

Tradition, modernity and social change in Angola

\section{Arlindo Barbeitos}

\section{(2) OpenEdition \\ Journals}

Edição electrónica

URL: https://journals.openedition.org/mulemba/211

DOI: $10.4000 /$ mulemba.211

ISSN: 2520-0305

Editora

Edições Pedago

\section{Edição impressa}

Data de publição: 1 novembro 2014

Paginação: 33-55

ISSN: 2182-6471

Refêrencia eletrónica

Arlindo Barbeitos, «Tradição, modernidade e mudança social em Angola», Mulemba [Online], 4 (8)।

2014, posto online no dia 28 novembro 2016, consultado o 16 fevereiro 2023. URL: http://

journals.openedition.org/mulemba/211 ; DOI: https://doi.org/10.4000/mulemba.211

Este documento foi criado de forma automática no dia 16 fevereiro 2023.

All rights reserved 


\title{
Tradição, modernidade e mudança social em Angola
}

Tradition, modernity and social change in Angola

\author{
Arlindo Barbeitos
}

\section{NOTA DO EDITOR}

Recepção do manuscrito: 15/11/2014

Conclusão da revisão: 20/12/2014

Aceite para publicação: 27/12/2014

1 O tema que vou abordar, infelizmente, de modo um tanto superficial dada a sua complexidade, é sem fora de dúvidas um dos mais candentes neste momento para a compreensão do nosso país. Mas, como se afirmou, devido a limitações várias, por inteiro alheias à nossa vontade, somos forçados a nos atermos a linhas essenciais desta matéria. Isto, quanto ao assunto, porque, em relação aos lugares, nos restringiremos às grandes urbes do litoral, ou não muito distantes dele. Por isso, esta grande cidade, meio urbe actual, meio «kimbo», em que Luanda se tornou, vai nos servir de exemplo maior.

2 Assim, comecemos pela tradição e os legados tradicionais; estes conceitos, a meu ver, pecam por alguma imprecisão científica. Isto, porque eles exemplificam, como muitos dos termos usados pelos cientistas sociais, as dificuldades que surgem dos meios da língua a que nos sentimos obrigados a recorrer, ou seja, a vocábulos de uma linguagem, neste caso, quase popular, sujeita a uma polissemia, não raro, vaga, senão de inconfessado sentido dúbio. Daí advêm quiproquós de diferente ordem, que não ajudam a uma meditação responsável e epistemologicamente séria, de um fenómeno social complexo e de grande relevância para a sociedade.

O substantivo tradição provém do latim traditio, de tradere, que finalmente, deu origem ao comum verbo trazer em português. Fazendo uma interpretação imediata deste trajecto etimológico, podemos concluir que a tradição consiste em um aspecto do 
imaginário que se traz consigo desde muito atrás. E o que se proferiu em relação a essa sumúla que nós portamos do antanho, permanece, outrossim, válido para os citados legados tradicionais, que consistem em continuidades e rupturas na citada tradição. Mas de donde é que vêm tais elementos desse vasto património ancestral, que nos garante a perservação da vida material e imaterial durante séculos e séculos? Ao senso comum, a resposta parece óbvia, para ele, a referida tradição e seus legados estão relacionados com o acervo cultural que levamos connosco, da língua, à cozinha, às instituições, como relações de parentesco a técnicas de abrigo, de trabalho e de defesa, dentre demais elementos, como crenças religiosas. As gentes trazem consigo, em sua memória colectiva e individual, esse vasto e compósito capital e o transmitem umas às outras de geração em geração. Deste jeito, agora já segundo a interpretação do antropólogo, ela se reportará obviamente ao passado e chega a nós, antes de tudo, pela via oral. Ela nos relata os mitos acerca das origens do universo, dos homens, os arquétipos que estes acarretam, a importância dos heróis fundadores e dos antepassados, as divindades da natureza, a religião, a magia, as suas representações mentais, os cultos da vida e da morte, o sagrado e o profano, os seus vínculos com os costumes e hábitos do quotidiano e tantas outras coisas que, no conjunto, definem a indentidade de um grupo social específico. Neste contexto da tradição, o peso do mito e das suas linguagens, se torna ainda mais claro para nós, quando descobrimos que ele nos mostra os laços fundamentais entre os seres humanos e o cosmos que nos rodeia $\mathrm{e}$ de que fazemos parte. Por causa de significado que nos transcende, o mito comanda os ritos, que incluem no campo social actos, que se repetem quase espontaneamente, e determinam as cerimónias decisivas, no campo do sacro, da vida, portanto do corpo e do espírito, como o nascimento, a iniciação, a doença, o extraordinário ou o óbito e até em âmbito mais profano, a etiqueta na relação com um mais-velho ou um superior. Desta argumentação, se infere que a tradição e os seus legados se convertem em traço essencial de uma qualquer cultura que os recebem, como que inconscientemente, do passado.

De modo excessivamente redutor ainda que operacional, sob o ponto de vista antropológico, se conclui que a dita cultura seria a soma dos valores, dos saberes teóricos e práticos que constroem as relações materiais e imateriais entre os homens e o seu meio-ambiente e também, entre si na comunidade e a transcendência presentes na língua. Daí advêm religião, a magia, os rituais, as instituições, os costumes, os hábitos, enfim a moral, que, em certo momento da sua existência, organizam enquanto corpo estrutural, a vida de um povo e lhe fornece um sentido basilar à continuidade no tempo e no espaço, expressos na palavra e nas formas de pensamento. Nesta qualidade, a cultura tem nas tradições e seus legados os seus medianeiros por excelência de como se está na vida e no mundo. Porém, ao contrário do que imaginaria um defensor ingénuo da tradição e de suas heranças, contínuas ou não, o observador, menos incauto que o comum dos cidadãos, pode verificar que nenhum povo consegue, impunemente se isolar na geografia e na história. Por conseguinte, todos, mais ou menos, ficam sujeitos a trocas culturais ao longo do seu trajecto pelas épocas sucessivas que o marcam e que vão alterando os referidos conteúdos tradicionais. Estes, também enquanto constituintes essenciais dos sistemas de pensamento e de linguagem, segundo os seus próprios meios - essas novidades - as foi, na mor das vezes, adoptando e logo integrando a si mesma, dir-se-ia quase imperceptivelmente.

5 Em Angola, este jogo de trocas culturais com o chamado Ocidente, começou relativamente cedo, quando comparado com outros Estados africanos da actualidade. 
Quer dizer, em uma era em que, mesmo em relação às Europas Ocidental e Central, a porção continental onde ela se iniciou, apenas pudéssemos falar de uma pré- ou protomodernidade, ou seja, o Renascimento, mais do que de uma modernidade propriamente dita.

Não será ousado, creio, admitir que no nosso país, a intensidade e o volume das trocas culturais e, desta feita, a capacidade de transformação decisiva, coincidiu com as sucessivas etapas da própria génese de Angola. Na realidade, o fenómeno transcultural em questão consistiu na acidentada travessia de um longo percurso anterior, o da tradição, suas continuidades e rupturas, e de seus modos, para o tempo hodierno, marcado por diferentes fases de modernidade, ou de transições oscilando entre presentes e passados distintos, ou seja, regimes de historicidade, enquanto modalidades de compreensão e representação do presente e do passado pelos povos e suas elites.

7 Historicamente, vale afirmar que em 1482, quando as caravelas lusas, enviadas por ordem de Dom João II de Portugal ao soberano mukongo Nzinga a Nkuwu, e levando consigo Diogo Cão, missionários, marinheiros e soldados, chegaram ao grande rio Zaire e ao Reino do Kongo, se abriu simbolicamente o primeiro capítulo do espinhoso tema que hoje trato aqui. Entre 1487 e 1491, o soberano Nzinga Nkuwu mandou estagiar em Portugal um grupo de aristocratas bakongo. Eles deveriam aprender, para além do português e do latim, a religião católica, a etiqueta da corte lisboeta e demais aspectos da cultura lusa da época. Estes gestos, dos quais foram actores um monarca africano, o seu congénere português e diversos africanos e ibéricos, penso, inauguraram o múltiplo e díspar processo de uma complexa e antiga relação, entre portugueses e africanos. Quero ainda destacar, neste âmbito de descobertas mútuas, uma nova e significativa embaixada de Lisboa, agora chefiada por Rui de Sousa e composta por missionários de distintas congregações, soldados, suas armas, de salientar as bombardas, artesãos e camponeses e respectivos instrumentos de trabalho, partiu, em caravana, do Pinda, o actual Soyo, para a capital do citado Estado, Mbanza Kongo. E, não menos relevante, foi o retorno, nesta comitiva, dos nobres bakongo que haviam estado em Portugal. Na capital do reino, os hóspedes europeus e africanos foram recebidos com pompa e circunstância por sua majestade Nzinga Nkuwu que foi, de imediato, baptizado juntamente com um número importante de nobres. Deste modo, uma nova e estranha religião foi introduzida neste espaço africano que, paulatinamente, se tornou em território do actual Estado angolano (RANDLES 1968: 87-104, 105-125; BALANDIER 1965: 29-52).

8 Como é do conhecimento geral, mais naquelas eras que na actualidade, uma religião envolvia um sistema de pensamento, portanto, uma visão do cosmos e dos homens. Ela continha valores, quadros de referência, comportamentos e atitudes, face ao natural e ao sobrenatural, que condicionavam a vida das populações. Ora, nesta senda mas sem pretender entrar em mais detalhes históricos que ultrapassam o escopo deste trabalho, desejo salientar, neste passo, a seita dos Antoninos, dirigida pela notável princesa real Kimpa Vita, Dona Beatriz. Esta senhora foi a principal mentora do partido africano em uma guerra civil, que de 1666 a 1706 - momento em que foi queimada como herege por ordem do Padre Capuchino italiano Bernardo da Gallo - assolou e devastou o Reino do Kongo. Duas linhagens reais, a dos Nlaza, apoiados pelos europeus e que, em aparência, aceitavam o catolicismo proposto pelos estrangeiros e a sua intromissão política, económica, social e cultural, e a dos Mpanzo que, embora havendo reformulado, ou seja africanizado, o cristianismo e demais elementos exteriores, defendiam o retorno a uma 
soberania endógena e sem interferência europeia. 0 conflito bélico foi terrível e custou àquele, antes pujante Estado proto-angolano, a riqueza de que havia gozado antes (Erika Sulzmann in MUEHLMANN 1964: 81-85).

9 O dramático conflito, que quiça abusivamente avançarei como avatar antigo do confronto, em Angola, entre o interno, local, e o externo, alienígeno, e a dolorosa entrosagem sincrética que ele ocasiona, coloca um sinal decisivo sobre as muitas configurações que a combinação destes elementos diversos traz consigo. Indiscutivelmente, a intromissão do inédito inovador, obrigou a um esforço mental de compreensão, de apreensão e de integração em si, que não devemos descurar. A religião cristã, as práticas comerciais europeias, as armas de fogo, os artefactos de ferro diferentes, as técnicas de construção - igrejas, conventos, casas edificadas de materiais ignorados até aí ou transformados de maneira estranha e o novo e brutal tráfico de escravos -, tiveram um impacto enorme que no nosso país é secular.

Conquanto, a aculturação enquanto fenómeno social múltiplo caracterizado por contactos culturais, mediante os quais as sociedades, ou comunidades menores, assimilam traços culturais, como língua, costumes, posturas, ideologias de povos diferentes, se tenha realizado entre nós, ao longo de fases diferenciadas por séculos e por estágios de ocupação distintos, a violência se manteve sempre como componente estruturante, ao serviço de um capitalismo principalmente mercantilista, que introduziu divisões do trabalho inéditas. Todo este processo principiou, para além de Mbanza Kongo, a partir de duas velhas urbes do litoral, Luanda (1576) e Benguela (1603), onde se concentrava a maior parte das autoridades portuguesas e da população branca e donde partiam não apenas intrusões militares ou missionárias, como as caravanas em busca de escravos. Por outro lado, elas encetavam as primeiras grandes dicotomias coloniais, ou seja, cidade/sertão ou «mato»; colonizadores/colonizados; cristãos/gentios; civilizados/bárbaros, que haveriam, ao longo dos séculos por condicionar as mais diferentes transações entre uns e outros e as diferentes maneiras de apreender e representar o mundo vivido e as coisas que o compõem.

11 Assim, dentre as demais novidades de fora, a arma, vejamos o velho bacamarte ibérico e a sua reinvenção autóctone como canhangulo, a pólvora, fundanga, a guerra, portanto tropa, igualmente, como o recurso à tipóia ou a maxila pelo português, pelo lusobrasileiro ou pelos grandes senhores angolanos, no decurso da História e nos mais variados lugares, constituíram elementos primordiais de aculturação reciproca.

Ora a nossa História, seguindo, apenas com interrupções de alguns decénios e de alterações de zonas de luta, indica que hostilidades, de maior ou menor intensidade, presidiram à formação do país. o facto está patente nas guerras de kwata-kwata, no nefando tráfico de escravos, nas chamadas «campanhas de pacificação», quer dizer, de conquista colonial, na luta armada de libertação nacional e na cruenta guerra civil, que somente em 2002 parece haver, enfim, terminado este deplorável ciclo de violência. Destaco este aspecto, porque ele, mal ou bem, cunhou inexoravelmente a conexão entre a cultura dos passados e dos presentes, que se foram sobrepondo e cruzando até à actualidade em Angola. E essas trocas mútuas foram obviamente efectuadas por seres humanos, no decurso de uma atribulada presença de portugueses, de início sobretudo judeus, de brasileiros, repetimos, de origem lusa, indígena ou mista, de indianos - em especial goeses -, e de africanos de proveniências díspares. Com essas pessoas vieram, logo nos primeiros séculos da ocupação colonial, produtos agrários, como a mandioca, o milho, o tomate, a batata «rena», o caju, o abacate, o abacaxi, a goiaba, a pitanga, a 
gajaja e outros produtos do Brasil, do Perú e do México, que os homens, ou melhor as mulheres de começo, adaptaram e, assim fazendo, transformaram a agricultura e os hábitos alimentares de angolanos do antigamente. Da Índia, vieram ter às nossas terras e aos nossos povos, a manga, o gengibre, o tamarindo e os belos panos de algodão, que até meados do século XIX, adornaram senhores e senhoras das velhas aristocracias e burguesias. Da China do século XVII, saíram as laranjas, os limões, as limas e tangerinas e sabe-se lá que mais. Todos esses produtos foram integrados na cultura tradicional angolana e actualmente, somente os especialistas conhecem essa proveniência (RANDLES 1974: 277-281). Contudo, no decurso destes primeiros estádios da influência portuguesa e brasileira, se deu a apropriação da escrita e do português por distintas elites nativas que, creio, em grau maior do que se acredita, marcaram decidamente o fascinante processo da formação das nossas culturas particulares e de suas elites (TAVARES e SANTOS 2002: 9-20, 23-43).

Podia estender este rol de coisas forâneas que se converteram em nossas e, desse jeito, se inscrevem na tradição que nos assinala ainda hoje. Elas abrangem as inertes, como armas de fogo, pólvora, tecidos, roupas, calçado, chapéus, maxila, sombrinha, jangada, mala, etc., etc., e vivas, tais como plantas e costumes, inclusive na cozinha típica, que se distingue doutros, por ser um dos domínios mais conservadores da nossa reprodução material e até imaterial. Também, e não menos importante, na esfera espiritual, está a dualidade, «alma»/«corpo» (mwenyu/mukutu, do kimbundu), desde de antanho, de modo comparável, no tempo e no espaço, aos círculos concêntricos cada vez maiores de uma pedra que se atira para a cacimba, se foi lenta mas seguramente, substituindo à ideia precedente da pessoa no nosso espaço bantu. Esta, de acordo com Luc de Heusch, é a aglutinação sintética de três «sombras», a primeira a solar, a mais íntima, ficava unida ao corpo e conduzia a um prolongamento metafísico e nos dava a imagem sedutora do duplo ou sósia e nos permitiria, se para isso tivessemos espaço, bastante especulação. A segunda sombra é representada pela figura e tamanho, ela persegue a nossa evolução fisica, do bébe ao idoso. Na terceira, se abriga o núcleo duro da pessoa. Dotada de mobilidade independente do corpo, ela vagueava por aqui e por acolá e transbordava a palavra; por isso, ela corria riscos de ser atacada pelas forças do mal, da dita feitiçaria. Após a morte, essa sombra deambulava pelas cercanias do túmulo e, então, se fixava nesse lugar cheio de mistério, Kalunga, também oceano (HEUSCH 1973: 232-242). Na minha adolescência, anos 50 do século XX, alguns mais-velhos kimbundu da minha região de nascimento, Icolo e Bengo, confirmaram uma visão bastante próxima da descrita pelo antropólogo belga.

Na realidade, as inovações penetraram lentamente aqui, a princípio, ou seja, a partir da segunda metade do século XIX e, depois, de modo mais rápido, na sequência da necessidade da potência colonial, pobre e atrasada, de rentabilizar as colónias. Isto, por intermédio de uma economia de plantações, em geral nas mãos de colonos, de artigos como o algodão, a cana-de-açucar, o dendé, o café e o sisal, que eram exportados para Portugal e para vários países industrializados. Os lucros obtidos pelos portugueses permitiram, principalmente, depois 1912-1915, que esse mencionado processo de modernização se manifestasse em África, todavia e antes do mais, em beneficio da «metrópole». Porém, por estranho que pareça, o Acto Colonial (1930-1932) imposto pelo regime reaccionário, retrógado e ditatorial de António de Oliveira Salazar à colónia, embora reduzisse a maioria esmagadora da população angolana, quase $99 \%$, à pura condição de mão-de-obra barata, despida de quaisquer direitos políticos, económicos e sociais, não deixou, indirectamente de atingir, pelo menos, o que restava da antiga 
burguesia dos angolenses e uma parte das aristocracias tradicionais, colaboracionistas ou não, ainda que camadas já assaz subalternizadas. Aliás, este desenvolvimento intensificou-se quando nos anos 50 do século XX, Angola se tornou o 3. maior produtor de café do mundo e o governo colonial introduziu, por essa altura, os ditos planos de fomento.

Como o veremos, o termo modernismo e daí modernidade, teve proveniência latinoamericana, nomeadamente literária; contudo, depois do seu surgimento entre fins do século XIX e inícios do seguinte, ele experimentou diversas metamorfoses até alcançar a actual chamada pós-modernidade, que, de longe ultrapassou o intuito e o significado originais. Com efeito, o conceito modernidade, brotou da ideia literária do «modernismo», cujas fontes se situam não no centro que desancadeou a evolução e o estado de coisas contemporâneo que dela proveio, mas sim da periferia hispanoamericana. Portanto, foi em 1890 que o poeta nicaraguaio Rubén Dario proclamou a criação de um movimento artístico-literário que denominou modernismo. 0 intento do autor se baseava na vontade de se separar por completo dos cânones estéticos espanhóis e de se inspirar nas culturas nativas do seu país e da sua América. $O$ conceito de modernismo conheceu múltiplas interpretações nos mais divergentes pontos do mundo e, nesse trajecto acidentado, ele se reduziu a moderno, novo, e daí nasceram as ideias de modernidade, de modernização e de pós-modernidade (ANDERSON 2005: 9-24, 25-64). No entanto, a modernidade, enquanto processo sobretudo marcado pela industrialização inglesa dos séculos XVIII e XIX e pelas ideias dos Iluminismos anglosaxónico, francês e alemão, que questionavam o Catolicismo e propunham o primado da razão assente na ciência, tangeram, assaz parcialmente, Portugal, quanto mais as colónias. Contudo, a intensidade desses movimentos europeus e norte-americano, acabaram por entrar nas maiores cidades da finisterra ibérica, mesmo se coxos e reduzidos a pequenas minorias privilegiadas. $\mathrm{E}$, entre os os meados e os fins dos séculos XIX, como reflexos, de um Portugal lutando pela sua sobrevivência como Estado independente e carecendo, para isso, das colónias africanas, Lisboa começou, então, um esforço de modernização de Angola de que as antigas elites angolenses beneficiaram, provisoriamente, bastante. Pelo menos em um primeiro tempo, depois elas se viram social e economicamente subalternizadas por colonos e, ademais, inferiorizadas pelo racismo (DIAS 1998: 458-470).

16 Mas afinal o que pretendemos dizer, quando no reportamos a esse complicado fenómeno que, segundo Jüergen Habermas, traria uma promessa de bem-estar e de felicidade que não foi cumprida, opinião, à sua maneira, corroborada por Alain Touraine (HABERMAS 1994: 32-51; TOURAINE 1992: 35-48). A famigerada modernidade se refere ao mundo condicionado e conformado pela industrialização capitalista, que implicara antes um impressionante desenvolvimento de uma razão instrumental e comunicacional aplicada às ciências e às técnicas, manifesta na organização do Estado, da sociedade e da economia, que juntos transformaram por completo a existência dos homens que tiveram a ocasião de experimentar essas novidades. Elas fomentaram a exploração dos recursos naturais - matérias-primas -, portanto indústria extractiva, a agricultura intensiva e extensiva, a produção transformadora de bens mercantis vários, o comércio e os serviços, logo o mercado monetarizado. Assim, concomitantemente, aumentaram o consumo e o lazer, ele próprio tornado em indústria cultural, por tendência, alienante de produtores e consumidores. 
17 A energia eléctrica, o comboio, a água entubada, o automóvel, os telefones, os grandes navios a vapor ou a outros combustíveis, a indústria do frio, o avião, a rádio, a televisão e, entretanto, a Internet, mudaram, radicalmente, o modo de ser e de estar dos homens na sociedade e na terra, pois engendraram modalidades do mundo vivido e de informação local e universal, em princípio, manipuladas por grandes grupos económico-financeiros multinacionais. Os seres humanos deixam de ficar, como particularmente entre nós em África, sobretudo dependentes de um chão dominado por uma agricultura, antes do mais de subsistência e por um comércio simples, de artigos artesanais, para ir, gradativamente, penetrando em um mundo diferente, em especial nas cidades, fabricado pelos homens, portanto, uma «segunda natureza» artificial, que os condiciona de um jeito desconhecido pelos seus avós. Como é evidente, as formações político-económicas e sociais, que desencadearam e mais fortemente viveram essas alterações racionalizantes, reificantes, burocratizadas e mercantilizadas das acções e das relações humanas, fabricaram sociedades e indivíduos hierarquizados novos. Elas se distanciavam, sobremaneira, de épocas anteriores, das formas de pensamento, de sentir e de comunicar imbuídas pelo imaginário do passado, ora ao excesso fragmentadas e, não raro, empobrecidas e inconsistentes, e sobretudo, mercantis. Isto, mesmo se a comunicação oral, a oralidade, persistam, apesar da dominação burocrática e autoritária da escrita e da fala em português, que atropelam em Angola a multiplicidade dos idiomas africanos.

18 Max Weber, a propósito de evoluções semelhantes no Ocidente europeu e norteamericano, que culminaram na separação da Igreja e do Estado que, dentre outros aspectos, caracterizaram nas citadas partes do globo, a passagem do Antigo para o Novo Regime, falou do «desencantamento - banalização - do mundo» (WEBER 1964: 311-339). $\mathrm{O}$ encanto da religião, das suas festas, das celebrações da família extensa cederam o lugar a um pensamento, dito racional, materialista e aparentemente frio, que singulariza o indivíduo contemporâneo, amurado em si próprio e desconectado desses laços imbuídos do maravilhoso ligado a essas manifestações, sacras ou profanas, que consolidavam a comunidade. Também a velha África, com tudo aquilo que ela possuía de extraordinário e especificamente local, foi desaparecendo e ninguém descreveu melhor o seu desvanecimento, que o grande escritor nigeriano Chinua Achebe, no seu famoso romance Things Falling Apart («Um mundo que se desfaz»). A maioria dos africanos actuais, formalmente, limitados à família monogâmica ou nuclear se muçulmanos, com frequência disfuncional, se perde na multidão anónima e aborrecida, por tendência caótica das grandes cidades resultantes do êxodo rural, fomentado pela atracção das luzes e da promessa, oh! tantas vezes vã, de uma existência melhor e de um sentido novo à vida e às coisas.

19 Todavia, de qualquer modo, penetraram na colónia desde a segunda metade do século XIX, coisas e ideias novas, como a iluminação a gaz em Luanda, o código de Morse, os correios, o Caminho de Ferro de Malanje e a noção do Estado laico, entre outras novidades. E, principalmente, com a República depois de 1910, com o Governador Norton de Matos, surgiu um impressionante programa de desenvolvimento, manifesto na construção de estradas e nos primeiros veículos a motor, por exemplo camiões, cujo intuito consistia em incrementar um mercado interno monetarizado, assente em produtos tropicais e alguma indústria, como a do açúcar e do óleo de palma. Na verdade, estas novidades foram gradualmente atingindo franjas cada vez mais vastas das populações angolanas, em particular, a dos centros urbanos, grandes e pequenos, 
espalhados pelo território da possessão (DÁSKALOS 2008: 55-84). Neste amplo campo material e espiritual de origem europeia, há que acrescentar a tremenda incidência das igrejas cristãs, a católica e as protestantes, como a Baptista, a Metodista e a Congregacionalista, sobre as populações urbanas e rurais instaladas no território (BIRMINGHAM 1999: 63-81).

Conquanto, se notasse na colónia uma notória evolução, que coincidia com o aumento do povoamento branco, as aviltantes condições de trabalho dos «indígenas», em particular nas zonas produtoras de café e de algodão - continuamente condenadas pela Organização Mundial do Trabalho (OMT), órgão das Nações Unidas - unicamente engendravam maior repressão. Assim, como resposta dos oprimidos, tivemos revoltas e levantamentos dos trabalhadores do algodão na Baixa de Cassange entre os anos $1958 \mathrm{e}$ 1960, o do 4 de Fevereiro em Luanda e o de 15 de Março no norte ocidental do território, ambos em 1961. Perante a gravidade da situação na colónia, Salazar nomeou para Ministro do Ultramar, o Prof. Doutor Adriano Moreira, homem culto, inteligente e fervoroso defensor da falácia do «Luso-Tropicalismo». Uma das medidas de maior alcance tomada pelo novo responsável das «Províncias Ultramarinas», foi a de abolir o Estatuto do Indigenato, que melhorou de imediato as condições de vida dos angolanos mais explorados. Nesta sequência, principalmente, depois de 1964, com o quase esmagamento da guerrilha no norte e enquanto resposta, à guerra de libertação, que se alatrava por outras regiões de Angola, Lisboa iniciou um impressionante processo de desenvolvimento, que não só incluiu a fundação dos Estudos Gerais - um núcleo universitário - e a instalação de escolas, que cobriram a maior parte do território, como promoveu a agricultura, o comércio e a indústria. A situação geral dos angolanos melhorou claramente sob todos os pontos de vista, visto Marcello Caetano, que em 1968 substituiu o velho ditador, entretanto, pretender criar uma burguesia angolana, negra, mestiça e branca, que demonstraria a validade do «Luso-Tropicalismo», como singularidade lusa. E para reforçar a presença portuguesa em África, vieram para cá, depois de 1964, cerca de 200.000 imigrantes portugueses e os poderes da polícia secreta, a temível PIDE, foram acrescidos. Estes dois factores traduziam a vontade do Estado Novo de não abrir mão da mais rica «Província Ultramarina» e, tanto quanto possível, retardar a sua independência.

21 Contudo, para Portugal, todo esse grandioso projecto assentava em pés-de-barro e, a 25 de Abril de 1974, ele ruiu com um Golpe de Estado levado a cabo pelos ditos «Capitães», e a nossa independência veio, a 11 de Novembro de 1975, em circunstâncias caóticas e brutais, que não interessa agora recapitular, pois, tal coisa ultrapassaria o escopo deste trabalho. Importa sim, sublinhar que a modernização que havia alcançado a ampla maioria dos angolanos, sofreu um rude golpe, pois, ela se baseava quase exclusivamente em quadros superiores «metropolitanos», pouco dispostos a aceitar uma dominação negra. Daí o exodo maciço da população branca, nascida aqui ou em Portugal, e de uma parte dos mestiços e de negros, demasiado compremetidos com o regime anterior ou, como para muita gente de todas as origens, apenas tementes da guerra e da terrível situação que se vivia no país. A despeito do esforço hercúleo do novo poder angolano em preservar o possível do patamar alcançado, mediante o recurso aos poucos quadros angolanos preparados e a cooperantes estrangeiros, provenientes do chamado «Bloco Socialista», houve a primeira e inevitável grande regressão, sobretudo, económica. No entanto, o maior e mais grave retrocesso, tendo em conta o facto que ele atingiu todos os sectores da vida dos angolanos, consistiu na cruenta guerra civil que assolou Angola de 1992 a 2002. Com efeito, a destruição de bens materiais e espirituais foi 
incomensurável e permitiu a um povo martirizado maneiras de sobrevivência regressivas, não raro bárbaras; muitas das aquisições da modernidade se converteram em formas ocas e as tradições mais autênticas se perderam com a morte de muitos mais-velhos e de níveis altíssimos de natalidade. Assim, entre as massas rurais, em grande parte desprovidas de referências antigas e novas, houve um aparente regresso ao passado. Ocorreu, por conseguinte, aquilo que muitas vezes acontece em tais situações pós-guerra, inventa-se tradição a partir de fanicos do passado, que a ignorância transfigura, não raro, em construções grotescas, mesmo criminosas, da chamada «feitiçaria», como a criminalização de crianças inocentes, acusadas de matar gente, com frequência familiares.

Saliento esta dimensão tradicional porque, quando hoje na periferia da cidade de Luanda, uma criança é acusada de bruxaria e de causar danos à família, assistimos muito provavelmente a uma transfiguração de crenças aldeãs onde resquícios inconscientes e distorcidos do imaginário anterior age, transfigurada e degradante de pobres camponeses, barbarizados pela guerra e pela incomensurável mudança sociocultural sofrida na grande urbe. Igualmente, as noções naturais de tempo e de espaço, antes profundamente ligadas entre si, de tipo circular espiralético, que nos concedia diferentes variantes do passado (Kilulu, do kimbundu, «o lugar dos antepassados») um presente prolongado com cambiantes dificilmente encontráveis em culturas europeias ou dessa raiz, foi entregando o seu posto a uma ideia, mesmo se difusa, linear acumulativa ocidental de tempo.

É interessante notar que em kimbundu, os conceitos de «dia» e de «tempo» coincidem, como se esta última dimensão fosse uma sequência de dias e, para além disso, a imagem de espaço kulu, quer dizer o território na cultura kimbundu porque é a que conheço melhor, no entanto, acho que os mesmos esquemas mentais são válidos para as nossas demais linguas e culturas. Julgo evidente que na dificuldade de muitos de nós em lidar com a pontualidade e de agir racional e convenientemente com os curto, médio e longo prazos na gestão, digamos, de uma empresa, subsistem vestígios inconscientes da velha tradição pré-colonial. o nosso ainda, para ainda não do «angolês», que designa algo que deveria ter acontecido, mas ficou por se passar, reproduz esse perceptível percurso do passado para o presente, que subsiste marcado no inconsciente de muitos angolanos. Acho que os dados mencionados demonstram, em simultâneo, uma transição e uma reinteprtação da noção do tempo portuguesa que, apesar de tudo, não coincide por completo com a original. Termino o assunto, reiterando que a nova visão do tempo, acumulativa e linear, surge-nos na contagem dos dias da semana, dos meses e dos anos, embora já esteja traduzida para a referida língua nacional.

Ao mesmo tempo, estas situações demonstram a crise de cosmologias anteriores, como construções imaginárias de crenças, conhecimentos, ritos, sistemas de referência e valores, enfim, um saber compósito que contém em si o universo natural, visões do sobrenatural e o humano. Elas incluem as cosmogonias enquanto explicações sobre a origem do universo e da sociedade e os respectivos mitos. Em Angola, devido a uma colonização que remontou ao termo da Idade Média europeia, nos séculos XV e XVI, componentes culturais ocidentais, em princípio cristãos, foram-se paulatinamente substituindo ou apenas se entrosando com as remotas idiossincrasias locais. Contudo, guerras e outros conflitos, sobretudo os mais recentes, foram produzindo perigosos vazios, por onde entram as mais diversas fantasmagorias, aproveitados, com frequência, por muitas das seitas evangélicas, sérias ou não, que enquadram gente 
desamparada, em particular as mulheres, ou seja, o sector da população que mais padeceu com as tremendas transformações, que a nossa sociedade global teve que suportar após a independência. Uma hermenêutica dos textos sagrados cristãos, oferecida pelas ditas seitas, literal, simples, solidária, sistematizada e eivada de milagres, facilita as gentes, por norma sem grande educação formal, um amparo espiritual e físico, ao transmitir calor humano, princípios orientadores e um sentido às suas existências precárias.

Importa esboçar agora, brevemente, os sucessivos estádios de mudança de tradição que antecederam em Angola, a modernidade propriamente dita. A cronologia podia estabelecer um primeiro período, que iria da viagem inicial de Diogo Cão, em 1482, ao fim do século XVIII e à independência do Brasil, em 1822; as cadências históricas foram lentas e se inseriram na longa duração. Contudo, os africanos conseguiram controlar a quantidade e a qualidade dos elementos estrangeiros a absorver e sincretizar nos seus idiomas e culturas, que iam acompanhando o nefando tráfico de escravos e, a não melhor, a escravatura.

Após uma longa e turbulenta transição, o segundo período angolano abre, quando em Portugal, na continuidade da vitória dos liberais na guerra civil que flagelou por uns anos a ex-potência colonial, o Marquês de Sá da Bandeira decretou, em 1836, a abolição da escravatura nas colónias e o tráfico de escravos. Embora, estas medidas tivessem largamente falhado, elas reflectiam em Angola os lampejos inaugurais da modernidade, ou seja a época da História Universal, que portava consigo os efeitos das industrialização inglesa e das revoluções Americana e Francesa.

Até no campo lúdico, durante aquela época de transição para novos tempos e modos de vida, entrou para a tradição urbana do espaço luandense e a ele associado, como a sua rectaguarda interior, uma dança galante de corte, de longínqua raiz italiana (minuetto). No século XIII, ela havia passado para a França e daqui foi para a Espanha, mais tarde, da Ibéria, ela seguiu para as suas colónias americanas, ainda durante o Antigo Regime. Já como «habanera» - de Havana, Cuba - uma mutação dessa dança europeia chegou, via Brasil e por cubanos, até nós e foi absorvida e reinterpretada pela tradição africana. Estamos perante a «Rebita»; a historiadora francesa, Anne Stamm, relata festas realizadas em salões de ricos angolenses, onde praticavam esse género de divertimento de salão. Dona Ana Ubertalli, ex-escrava do Kwanza-Sul, que impressionara de tal modo, pela sua beleza e pela sua inteligência, o deportado italiano, senhor Ubertalli seu dono, pagou-lhe uma educação europeia e acabou por casar com ela. Já viúva e riquíssima, como nos conta Anne Stamm, esta dama, aquando da tomada de posse do Governador Geral, Lourenço Germack Possolo, 1844-1845, abriu a festa, bailando com aquele senhor, goês de origem (STAMM 1971: 58-91). Enfim, voltas e contra-voltas da nossa História.

Mas, como se afirmava, o poder colonial ansiava substituir os bens ilícitos, os escravos e os contrabandos diversos, por bens lícitos, marfim, urzela, cera, couros, borracha, café, algodão e cana de açúcar sujeitos a impostos legais e converter o trabalho em livre e assalariado. Como disse, esse período que, para mim, finda em 1890, envolve já uma mais vasta introdução de elementos materiais novos que, em eras anteriores se desconheciam, e uma mais vasta aculturação de angolanos dos velhos centros urbanos e do interior, aceitada de bom grado, pelos filhos-da-terra. Aos 13 de Setembro de 1845, na continuidade da decisão do Governador Geral Pedro Alexandrino da Cunha, foi publicado em Luanda o Boletim Official do Governo Geral da Província de Angola. Mais tarde, 
em Maio de 1849, o negociante de escravos e fazendeiro milionário madeirense, Arsénio Pompílio Pompeu do Carpo, ofereceu ao governo colonial uma tipografia bem apetrechada que importara da Europa (LOPO 1964: 11-15). Este boletim, algo memorável na África da altura, incitou posteriormente ao desenvolvimento, em Luanda e a seguir em Benguela e em Moçâmedes, de uma imprensa angolana que, a partir dos finais do decénio de 1870 , se foi tornando proto-nacionalista ou mesmo nacionalista no significado actual. Estes periódicos, bastantes na posse de angolanos - os angolenses -, eram, usualmente, semanais ou quinzenais. Neles, escreveram bem, melhor que hoje em geral, eminentes jornalistas, como José de Fontes Pereira, que pugnavam pelo ensino generalizado e o desenvolvimento da colónia. Aí, nos deparamos, de novo, com os primórdios da modernidade como a temos na actualidade (WHEELER 1970: 854-874).

Durante este período caravanas de mercadores angolanos, mais ou menos europeizados, sulcavam os velhos caminhos, vindos de eras longínquas, não só em busca, já ilegal, de escravos, marfim, cera e borracha silvestre, mas também vendiam produtos oriundos das fábricas europeias. Deste modo, sem me referir ao sal, se espalhavam em pleno século XIX por Angola, tecidos, sabão, fósforos, medicamentos, velas, lamparinas, vasilhames de metal, e instrumentos de trabalho importados, para sapateiros, alfaiates, pedreiros, carpinteiros, e de demais profissões. Destas, a maioria havia sido aprendida com missionários europeus, séculos antes e tinha sido transmitida de pais para filhos, segundo rituais que já integravam elementos europeus e africanos. Neste caso, para mim fascinante e nada estudado, se combinavam já tradição e modernidade, quase avant la lettre. Repito, nesta etapa de transformação, os nossos povos ainda controlavam as modalidades de aceitação e de recusa em suas línguas e suas culturas dos diferentes elementos culturais a absorver ou a refutar. Ainda em meados do século XIX, há que salientar, a demasiado esquecida inauguração e existência de uma companhia de carreiras de navegação, ligando nos dois sentidos Luanda e Dondo, pertencente ao empresário luso-americano Archer da Silva (cf. Boletim Official do Governo Geral da Província de Angola, 1866: 298-302).

Estes pitorescos barcos, relativamente grandes, transportavam mercadorias e passageiros de um lugar para o outro; aquela urbe do interior era então um opulento empório da cera, todavia em mãos de angolanos - angolenses - do qual Angola foi um produtor de dimensão mundial. Entretanto, a produção agrícola havia aumentado com a introdução, em escala considerável, do café, do algodão e da cana-de-açúcar, plantados nos antigos arimos, ou nas roças, propriedade de angolanos, por vezes com antepassados, mais ou menos distantes, brasileiros ou portugueses, veêm a ser substituídos, a partir dos últimos decénios do século XIX, por fazendas, viradas para a exportação, em larga escala em posse de europeus. Contudo, ao contrário do que havia sempre sobrevindo em épocas precedentes, conquanto ainda elevada, diminuiu a proporção de matrimónios mistos, depois da chegada de mulheres brancas em porção importante, desde fins dos anos 80 daquele século. Estes factores, decorrentes em absoluto da modernidade, se ligam ao desenvolvimento no Ocidente das ciências e das técnicas, designadamente, da medicina, de medicamentes eficientes contra diferentes enfermidades tropicais ou não e do saneamento básico. Uma prova de extrema importância dessa evolução está bem patente na inauguração, em Luanda, do Hospital Maria Pia (hoje Josina Machel, nome de uma heroína moçambicana, da luta armada de libertação nacional daquele país) em 1893. À altura, foi considerado um dos melhores de África. 
31 A partilha de África, dos anos 80 desse século em diante, fez parte de uma divisão do mundo pelos Ocidentais, que portava até o seu cume o Estado liberal, ele mesmo um filho da modernidade que, se de um lado defendia e reforçava a democracia formal no interior do seu espaço nacional, por outro lado exportava para os povos subjugados um sistema totalitário, outrossim, portador de inovação imposta. Esta aporia, que as potências europeias imperialistas traziam consigo e não conseguiam resolver, sem abolir a sua dominação, acabou por destruir o colonialismo directo. Portugal, que por causa do seu visível subdesenvolvimento não desenvolvera modernidade endógena, por conseguinte, a importou e reexportou para a África, de acordo com as conveniências das suas lideranças, que estavam, à altura, na manutenção da sua independência diante da Espanha. A aquisição de um império colonial conferiu a esse pequeno e atrasado país, cujas elites se sentiam inferiorizadas face à Europa Ocidental, um enorme capital simbólico de que elas, atendendo às suas fragilidades, não sabiam abdicar.

Em minha opinião, uma das razões do elevado grau da aculturação da maioria das populações angolanas se deve, não somente à antiguidade das interacções entre uns e outros, mas principalmente à debilidade, material e imaterial, senão mesmo ao atraso histórico do imigrante luso cá. Este facto, julgo, em comparação com as demais colonizações europeias em África, diminuía distância social entre brancos e negros; ou a tornava variável de acordo com as circunstâncias e, desta feita, ao mesmo tempo aumentava a possiblidade de conflito e de aliança, de acordo com as relações de força prevalecentes no espaço e no tempo.

O terceiro período, cujas consequências perduram na actualidade, principiou em 1890, com a dramática mudança de paradigma de dominação colonial e durou até ao Acto Colonial, imposto pelo ditador António de Oliveira Salazar, em 1930-1932. Esta época viu a entrada em força daquilo que se chama modernidade na colónia. As nossas gentes foram, então lenta e inexoravelmente despojadas dessa capacidade autónoma, por exemplo, o português já se não aprendia por vontade própria, mas por rude imposição, que implicava muitas vezes o recalcamento do idioma angolano. 0 mundo dos brancos começou a se tornar, como paradigma maior de cultura, senão o único, a adoptar por qualquer angolano, para melhorar a sua condição existencial e para ser considerado «civilizado». Contudo, essa modernidade, já se iniciara no período final da Monarquia, deste modo, se estendeu gradualmente a rede de água corrente a Luanda, em 1889, sensivelmente pela mesma época se expandiu a iluminação a gás em umas quantas ruas e praças da cidade. Um pouco mais tarde, os correios e os telégrafos - estes recorriam ao alfabeto de Morse - se abriram a sua extensão pelo nosso espaço. A instalação por uma empresa britânica, no dealbar do século XX, do cabo submarino agilizou as comunicações entre Luanda e Lisboa e também aproximou as cidades do nosso litoral umas das outras. O Caminho de Ferro de Ambaca, hoje de Malanje - encetado em Luanda em 1887, que atingiu o Lukala em 1889 e Malanje em 1910, depois de uma odisseia que demonstrou claramente a fragilidade do colonialismo de Lisboa desempenhou um papel enorme na modificação dos hábitos de muitos povos locais, como aliás os de Benguela e de Moçâmedes. Eles estabeleciam, nos centros urbanos por onde transitava o comboio, pequenos núcleos de angolanos diferentes dos seus antepassados e que, paulatinamente, iam mudando as suas visões das coisas, das pessoas e do mundo. Nesse comenos, se alargavam as derradeiras conquistas coloniais e se multiplicavam as ditas "guerras de pacificação», que mostraram aos resistentes 
angolanos e às suas comunidades, o impacto das novas armas de fogo (FREUDENTHAL 2001: 260-467; TELO 1994: 133-197).

34 A nomeação de Norton de Matos, já pela República Portuguesa, instaurada a 5 de Outubro de 1910, para um 1. mandato, em 1912-1915, para dirigir a colónia significou um salto decisivo para o complexo processo da implantação difinitiva dos componentes jurídico-administrativos e infraestruturais da modernidade em Angola. A despeito da penúria de meios da própria metrópole, este «Alto Comissário» contraiu empréstimos em bancos estrangeiros para a realização de grandes obras, nas esferas económica, financeira, social e cultural, que se reproduziram em um substancial aumento da capacidade de intervenção colonial sobre as populações africanas. Um desses elementos básicos dessa modificaçâo consistiu em mandar erguer ou restaurar portos marítimos, toda uma rede de pontes e de estradas macadamizadas por todo o espaço angolano. Para circularem por tais rodovias, que se sobrepunham aos antigos caminhos das vetustas redes do comércio pré-colonial, foram oficialmente importados os primeiros veículos automóveis, ligeiros, médios e pesados. E, como se pode deduzir, surgiu a primeira legislação local sobre vias carreteiras e sobre essas viaturas. Neste âmbito, foram constituídas equipas de tabalhadores «indígenas», encarregadas de manter em bom estado de conservação todos esses empreendimentos. Essas inovações iam, finalmente, ajudar a resolver o complicado e velhíssimo problema do "carreto» transporte de mercadorias por carregadores humanos do litoral em direcção ao interior e em sentido contrário. Mas, também aqui, descobrimos um nexo de tradição, seus legados e de modernidade nessa imbricação de rotas de distintas eras. Não só para todos estes serviços, como ainda para a edificação de edifícios representativos do poder do Estado e para a sua manutenção (TELO 1994: 67-100; 103-130).

35 A fim de se garantirem os serviços que tais novidades envolviam, foi indispensável formar todo um corpo de quadros angolanos, pois escasseava o número de portugueses aptos ou dispostos a assumir os referidos postos. Assim, vimos o aparecimento de um género inédito de funcionários públicos nativos, em diversos escalões, nomeadamente do correio, do caminho-de-ferro, da fazenda, dos portos, etc. Porém, igualmente, o incremento do comércio privado, cada vez mais em mãos de portugueses, porque o Banco Nacional Ultramarino - instalado em Luanda desde 1875 -, lhes concedia créditos mais facilmente que aos «filhos-da-terra», levou a um acréscimo de empregados comerciais angolanos. A estas profissões, predominantemente urbanas, se juntaram continuamente outras, em geral não ligadas ao Estado, tais como, por exemplo, motoristas, mecânicos ou serralheiros. Contudo, os antigos ofícios, ou seja pedreiros, carpinteiros, mercerneiros, sapateiros ou alfaiates sofrerão grandes alterações, já que haviam surgido técnicas e instrumentos de trabalho mais elaborados e outras modas de vestimenta e de calçado, que forçaram a adaptações dos quadros.

Angola, a seu tempo viveu todas essas mudanças que, de certo modo, se incluen no precesso secular da formação do nosso país. Todavia, outras vêm já após a nossa independência, a 11 de Novembro de 1975, porque, com a instauração do Estado, traços singulares angolanos se foram acumulando e combinando e, no decurso de gerações, se expandiram desigual mas, inexoravelmente, por Angola afora. Esses aspectos, um tanto tumultuosamente devido à guerra, equivalem a reformulações, entrosadas entre si, das culturas locais e da portuguesa colonial, em parte já adaptada, como se nota nas variantes do português angolano. E mesmo na cozinha, que constitui um elemento essencial da cultura de um povo, constatamos, com a entrada do bacalhau na nossa 
cultura, um grau de aculturação pouco comum em África. O conjunto desses ingredientes, enquanto processo assimétrico, de formas e de profundidades diversas, constrói identidades várias que confluindo dão, formas de angolanidade como processo em curso. Essas reinterpretações, divergentes, de acordo com os estratos sociais e as regiões do país, vão da cozinha, espaço por excelência das trocas culturais, a hábitos e a atitudes face ao mundo da vida, quer no campo quer na cidade, que penetra ali pela rádio, pela televisão, pelo telefone portátil e pelas visitas de gente citadina, que vão ao encontro de parentes na sede da província ou na capital do país.

\section{BIBLIOGRAFIA}

ANDERSON Perry, 2005, As origens da pós-modernidade. Tradução do inglês por Artur Morão. Lisboa, Edições 70.

BALANDIER Georges, 1965, La vie quotidienne au Royaume du Congo, du XVIe au XVIIIe siècle. Paris, Hachette.

BIRMINGHAM David, 1999, Portugal and Africa. Londres, MacMillan Press.

Boletim Official do Governo da Provincia de Angola, 1866, n. 39, 29 de Setembro, pp. 298-302.

DÁSKALOS Maria Alexandre, 2008, A política de Norton de Matos para Angola 1912-1915. Coimbra, Minerva.

DIAS Jill, 1998, «Angola» in Valentim Alexandre e Jill Dias (coords.), Império Africano, 1825-1890, vol. $X$ de Nova história da expansão portuguesa, sob a direcção de Joel Serrão e A. H. de Oliveira Marques. Lisboa, Editorial Estampa, pp. 458-470.

FREUDENTHAL Aida, 2001, «Angola», in A. H. de Oliveira Marques (coord.), O Império Africano, 1890-1930, vol. XI de Nova história da expansão portuguesa, dirigida por Joel Serrão e A. H. de Oliveira Marques. Lisboa, Editorial Estampa, pp. 260-467.

HABERMAS Jüergen, 1994 (3. a edição), Die moderne - Ein unvollendes projekt. Leipzig, Reclam Verlag.

HEUSCH Luc de, 1973, «Le sorcier, le Père Tempels et les jumeaux mal venus», in La notion de personne en Afrique Noire. Paris, Centre National de la Recherche Scientifique, pp. 232-242.

LOPO Júlio de Castro, 1964, Jornalismo de Angola. Subsídios para a sua história. Luanda, Centro de Informação e Turismo de Angola.

MUEHLMANN Wilhelm, 1964, Chiliasmus und nativismus. Studien zur psychologie, soziologie und historischen kasuistik der umsturtzbewegungen. Berlin, Dietrich Reimer Verlag.

RANDLES W. G. L., 1968, L'ancien royaume du Congo dès origines à la fin du XIX siècle. Paris - La Haye, Mouton \& Co.

RANDLES W. G. L., 1974, «La civilisation bantou, son essor et son déclin», in Annales. Économies, Sociétés, Civilisations (Paris), 29.ํ Ano, n.ำ 2, Mars - Avril, pp. 277-281. 
STAMM Anne, 1971, L'Angola à un tournant de son histoire, 1838-1848. Paris, École Pratique des Hautes Études.

SULZMANN Erika, 1964, «Die bewegung der Antonier im alten Reich Kongo», in Wilhelm Muehlmann, Chiliasmus und nativismus. Studien zur psychologie, soziologie und historischen kasuistik der umsturtzbewegungen. Berlin, Dietrich Reimer Verlag, pp. 81-85.

TAVARES Ana Paula e SANTOS Catarina Madeira, 2002, Africae Monumenta. A apropriação da escrita pelos africanos, volume I, Arquivo Caculo Cacahenda. Edição, introdução, glossários e textos por Ana Paula Tavares e Catarina Madeira Santos. Lisboa, Centro de Estudos de História e Cartografia Antiga; Instituto de Investigação Científica Tropical.

TELO António José, 1994, Economia e império no Portugal contemporâneo. Lisboa, Edição Cosmos. TOURAINE Alain, 1992, Critique de la Modernité. Paris, Fayard.

WEBER Max, 1964, Soziologie. Weltgeschichtliche analysen, politik. Estugarda, Alfred Kroener Verlag. WHEELER Douglas, 1970, «Early angolan protest: the radical journalism of José de Fontes Pereira (1823-1891)», in Robert I. Rotberg \& Ali Mazrui (eds.), Protest and power in Black Africa. New York, Oxford University Press, 1970.

\section{RESUMOS}

Neste artigo, explicam-se as reações, tais como as absorções ou rejeições, dos vários povos angolanos, ou parte deles, às inovações, introduzidas por portugueses, brasileiros, indianos e africanos, às suas comunidades. Consideramos, portanto, a relação diacrónica entre modernidades, contínuas ou discontínuas, e as tradições ou legados tradicionais em Angola.

In this article are explained the reactions of several Angolan people, such as the absorption or rejection, to the innovations introduced by the Portuguese, Brazilian, Indians, and Africans to their communities. We therefore consider the diachronic relationship between modernities, continuous or discontinuous, and the traditions or traditional heritage in Angola.

\section{ÍNDICE}

Palavras-chave: tradição, legado tradicional, modernidade, pós-modernidade, transição, guerra, regressão, seitas

Keywords: tradition, traditional heritage, modernity, postmodernity, transition, war, regression, sects

\section{AUTOR}

\section{ARLINDO BARBEITOS}

arlindo_barbeitos@yahoo.com.br

Professor Auxiliar do Departamento de Sociologia (DS) e Coordenador do Centro Avançado de Estudos Africanos (CAEA) da Faculdade de Ciências Sociais (FCS) da Universidade Agostinho Neto (UAN).

Doutorado em Sociologia pela Universidade da Beira Interior (Covilhã, Portugal), é Professor Auxiliar do Departamento de Sociologia (DS) e Director do Centro Avançado de Estudos Africanos 
(CAEA) da Faculdade de Ciências Sociais (FCS) da Universidade Agostinho Neto (UAN). Além de investigador na área das Ciências Sociais e Humanas, é escritor membro da União dos Escritores Angolanos (UEA), sendo um dos seus fundadores em 10 de Dezembro de 1975. Publicou as obras, textos esparsos e artigos seguintes: Angola-Portugal. Representações de si e de outrem ou o jogo equívoco das identidades (2010); Angola-Portugal: des identités coloniales equivoques. Historicité des representations de soi et d'autrui (2008); A sociedade civil, Estado e identidade em Angola (2005; 2008); Considerações críticas de um angolano sobre Fernando Pessoa (2004); «Prefácio», in David Birmingham, Portugal e África. Traduzido do inglês por Arlindo Barbeitos (2003); «Oliveira Martins, Eça de Queiroz, a raça e o homem negro», in Maria Emília Madeira Santos (coord.), A África e a instalação do sistema colonial, c. 1885- c. 1930 (2000); «O conceito de África e o direito de classificar: relação entre sujeito e objecto e a questão da identidade», Mulemba - Revista Angolana de Ciências Sociais (Luanda), vol. II, n.․ 3, Maio de 2012, pp. 9-33; «O Mali. Destruição de um Estado africano na era global», Mulemba - Revista Angolana de Ciências Sociais (Luanda), vol. II, n. 4, Novembro de 2012, pp. 179-190; «A desconstrução histórica do conhecimento exógeno africano. Elementos para uma leitura sistemática de A invenção de África. Gnose, filosofia e a ordem do conhecimento, do filósofo congolês V.Y. Mudimbe», Mulemba - Revista Angolana de Ciências Sociais (Luanda), vol. III, n. 5, Maio de 2013, pp. 141-149; «Que Sociologia para a África e para Angola?», Mulemba - Revista Angolana de Ciências Sociais (Luanda), vol. IV, n.ำ 7, Maio de 2014, pp. 95-131. Publicou ainda as seguintes obras literárias: Na leveza do luar crescente (1999); Fiapos de sonho (1993; 1992); O rio. Estórias do regresso (1985; 1979); Nzoji, Sonho (1979); Angola, Angolê, Angolema (1976; 1974). Foi vencedor do «Prémio Nacional de Cultura e Artes», na disciplina de Ciências Humanas e Sociais, no ano de 2011. É membro do Conselho Científico da Mulemba - Revista Angolana de Ciências Sociais. 